\title{
Immunohistochemical Distribution and Quantitative Biochemical Detection of Advanced Glycation End Products in Fetal to Adult Rats and in Rats with Streptozotocin-Induced Diabetes
}

\author{
Xia Ling, Ryoji Nagai, Naomi Sakashita, Motohiro Takeya, Seikoh Horiuchi, and \\ Kiyoshi Takahashi
}

Second Department of Pathology (XL, NS, MT, KT) and Department of Biochemistry (XL, RN, SH), Kumamoto University School of Medicine, Kumamoto, Japan

\begin{abstract}
SUMMARY: We used immunohistochemical methods and four monoclonal antibodies for specific molecular structures of advanced glycation end products (AGE)-6D12, KNH-30, 1F6, and 2A2-to examine localization of AGE in fetal, young, and adult rats, and rats with streptozotocin-induced diabetes. $6 \mathrm{D} 12$ recognized $N^{\epsilon}$-(carboxymethyl)lysine $(\mathrm{CML}) ; \mathrm{KNH}-30, N^{\epsilon}-$ (carboxyethyl)lysine (CEL); and 1F6, fluorolink. The epitope of 2A2 is as yet unknown. Immunoreactivities for these monoclonal antibodies were found in various organs and tissues in postnatal and adult rats, and accumulation increased with aging. In the fetuses, AGE structures were detected at 10 fetal days, and their accumulation increased during ontogeny. Reversed-phase high-performance liquid chromatography revealed CML in fetuses at 13 fetal days and in lungs of 28-week-old rats. In various organs and tissues of fetal, young, and adult rats, CML, CEL, 2A2-positive AGE, and fluorolink accumulated, in that order, which suggests that the accumulation of CML, a nonfluorescent/noncross-linked AGE, occurs earlier than accumulation of fluorolink, a fluorescent/cross-linked AGE. In diabetic rats, hepatocytes, splenic macrophages, renal glomerular endothelial and mesangial cells, testicular Leydig cells, and erythrocytes showed excessive accumulation of AGE, leading to the pathologic changes characteristic of diabetes mellitus. For the induction of these changes, persistent hyperglycemia and hyperketonemia might be important for acceleration of intracellular AGE accumulation in diabetic rats. Thus, AGE accumulation in tissues and cells occurs not only during aging and in diabetes mellitus but also from an early stage of ontogeny. (Lab Invest 2001, 81:845-861).
\end{abstract}

\begin{abstract}
A dvanced glycation end products (AGE) of the Maillard reaction are formed via the nonenzymatic glycation of proteins with reducing sugars (Maillard, 1912), such as glucose, glucose 6-phosphate, and ribose, and are composed of heterogeneous molecular structures characterized by a yellow-brown color, autofluorescence, and intra- and intermolecular cross-linking. Although the molecular structures of AGE remain unknown, pyrraline (Hayase et al, 1989), pentosidine (Sell and Monnier, 1989), cross-lines (Nakamura et al, 1992), $N^{\epsilon}$-(carboxymethyl)lysine (CML) (Ahmed et al, 1986), $N^{\epsilon}$-(carboxyethyl)lysine (CEL) (Ahmed et al, 1997), fluorolink (Horiuchi et al, 1996), glyoxal-lysine dimer (WellsKnecht et al, 1996), methylglyoxal-lysine dimer (Degenhardt et al, 1998), imidazolone (Niwa et al, 1997), and vesperlysines A, B, and C (Nakamura et al, 1997) are known to be AGE-specific molecules. These AGEspecific structures have been shown to accumulate in animal and human tissues during aging (Araki et al, 1992) and prominently in various human diseases such as diabetes mellitus (Vlassara et al, 1994), atherosclerosis
\end{abstract}

Received February 14, 2001.

Address reprint requests to: Dr. Kiyoshi Takahashi, Second Department of Pathology, Kumamoto University School of Medicine, 2-2-1 Honjo, Kumamoto 860-0811, Japan. E-mail: lingxia@kaiju.medic.kumamoto-u.ac.jp
(Kume et al, 1995), amyloidosis (Hoshii et al, 1996), Alzheimer's disease (Sasaki et al, 1998), neurodegenerative diseases (Sasaki et al, 1998), Lewy body disease (Castellani et al, 1996), actinic elastosis (Mizutari et al, 1997), rheumatoid arthritis (Miyata et al, 1998), and pulmonary fibrosis (Matsuse et al, 1998).

Our previous immunohistochemical study demonstrated the intra- and extracellular accumulation of AGE in various organs and tissues of adult humans by using monoclonal antibodies recognizing different AGE-specific structures such as CML and fluorolink (Ling et al, 1998). These different AGE-specific molecules were demonstrated in macrophages widely distributed in various organs and tissues: endothelial cells of the endocardium, arteries, veins, and blood capillaries; mesenchymal cells; epithelial and parenchymal cells; blood cells; and extracellular matrix. Immunoelectron microscopy demonstrated the localization of AGE-positive immunogold particles in nuclei, nuclear envelopes, mitochondria, endoplasmic reticula, Golgi complexes, endocytic vesicles, lysosomal vacuoles or granules (including ceroid/lipofuscin), secretory granules, cytosol, and cell membranes, as well as in the extracellular matrix. AGE are thus formed intranuclearly and intracellularly as well as extracellularly (Ling et al, 1998). 
In addition to endogenous production of AGE, oral intake and intestinal resorption of AGE are known to be environmental risk factors for diabetic nephropathy (Koschinsky et al, 1997). The formation processes of structures of AGE molecules are chemically irreversible, and studies have provided evidence that AGEmodified proteins in serum are degraded by the liver (Youssef et al, 1998) and kidneys (Dolhofer-Bliesener et al, 1995); that AGE bind to and are taken up by a variety of cells via receptors such as macrophage scavenger receptors (Nagai et al, 2000; Suzuki et al, 1997), receptor for AGE (Fehrenbach et al, 1998), and galectin-3 (Vlassara et al, 1995); and that AGE are generated from lipids (Bucala et al, 1993) and nucleic acids (Bucala et al, 1984) as well as from proteins.

The biosynthetic pathways of AGE in vivo have not yet been elucidated; however, several studies reported that AGE-specific molecules are generated through different metabolic pathways (Nagaraj et al, 1996; Odani et al, 1998; Uchida et al, 1997). During incubation of proteins with glucose, glycolaldehyde (Glomb and Monnier, 1995; Nagai et al, 2000), glyoxal (Glomb and Monnier, 1995; Wells-Knecht et al, 1995), and methylglyoxal (Thornalley et al, 1999) are generated as intermediates that react with proteins to yield AGE. In addition to glycolaldehyde derived from the Maillard reaction, the myeloperoxidase pathway was also reported to generate glycolaldehyde, involving AGE formation in vivo (Anderson et al, 1999; Daugherty et al, 1994; Nauseef, 1988; Tobler and Koeffler, 1991). Glyoxal and methylglyoxal are reactive dicarbonyl compounds formed during autoxidation of both carbohydrates and lipids via the polyol pathway (Thornalley, 1996; Thornalley et al, 1999) or are produced nonenzymatically by spontaneous decomposition of triose phosphate intermediates in glycolysis (Richard, 1991). Methylglyoxal is also an intermediate product in the catabolism of ketone body acetone (Reichard et al, 1986). Polyol pathway activity is known to be increased in diabetic patients, and plasma methylglyoxal concentration increases significantly in diabetic patients compared with concentrations in healthy subjects (Mclellan et al, 1994). Rapid formation of AGE by intermediate metabolites of the glycolytic and polyol pathways was reported under physiologic conditions (Hamada et al, 1996). In addition, it is known that oxidation plays an important role in CML formation (Nagai et al, 1997). Although AGE have been extensively studied in aging and in various diseases (Araki et al, 1992; Castellani et al, 1996; Hoshii et al, 1996; Kume et al, 1995; Matsuse et al, 1998; Miyata et al, 1998; Mizutari et al, 1997; Sasaki et al, 1998; Vlassara et al, 1994), little is known about the generation of AGE during development, and there are few systematic experimental studies of the production of AGE in aging and diabetes mellitus in vivo.

To investigate the distribution of AGE in various tissues of fetal and adult rats, and the relationship between AGE accumulation and aging and diabetes mellitus, we performed immunohistochemical studies of rat fetuses, young and adult rats, and rats with streptozotocin (STZ)-induced diabetes by using four monoclonal antibodies: 6D12, $\mathrm{KNH}-30,2 \mathrm{~A} 2$, and $1 \mathrm{~F} 6$. 6D12 recognized $\mathrm{CML}$; $\mathrm{KNH}-30, \mathrm{CEL}$; and $1 \mathrm{~F} 6$, fluorolink. The epitope of $2 \mathrm{~A} 2$ is unknown, but this AGE-specific molecule is different from $\mathrm{CML}$ and fluorolink and other known AGE-specific structures such as pyrraline, pentosidine, and cross-lines. We used reversed-phase high-performance liquid chromatography (RP-HPLC) for a quantitative biochemical evaluation of $\mathrm{CML}$ in rat fetuses and lungs of adult rats. Our data demonstrate that AGE accumulate in various organs and tissues of rat fetuses, young and adult rats, and STZ-induced diabetic rats.

\section{Results}

\section{Immunohistochemical Localization of AGE in Various Organs and Tissues in Postnatal and Adult Rats}

Table 1 shows the immunohistochemical localization of AGE in rats at birth and at 4 and 8 weeks and 2 years of age. By use of the anti-AGE monoclonal antibodies $\mathrm{KNH}-30,6 \mathrm{D} 12,2 \mathrm{~A} 2$, and 1F6, AGEpositive deposits of different intensities were demonstrated in various organs and tissues. The emergence stage and distribution pattern of the AGE-specific molecules were different among the various age groups. At birth, the positive reaction products of all four antibodies were found in the cardiomyocytes (Fig. 1A), bronchial epithelial cells, cartilage cells (Fig. 1B), alveolar macrophages in lungs, splenic red pulp macrophages (Fig. 1C), and renal tubular epithelial cells. In contrast, no positive reactions were found in goblet cells or mucous epithelial cells of the alimentary and respiratory tracts, even at age 2 years.

In other tissues and organs, positive reactions for these monoclonal antibodies varied among age groups. In hepatocytes, positive reactions for $\mathrm{KNH}-30$ and 6D12 were demonstrated at birth; for 2A2, at 4 weeks of age; and for 1F6, at 8 weeks of age. Kupffer cells showed positive reactions for 1F6, 2A2, 6D12, and $\mathrm{KNH}-30$ at Day 0, 4 weeks, 8 weeks, and 2 years of age, respectively. Endothelial cells of renal glomeruli showed positive reactions for 1F6 from 8 weeks on, and for the other antibodies at 2 years of age. Epithelial cells of the gastrointestinal tract displayed positive reactions for $\mathrm{KNH}-30$ and $6 \mathrm{D} 12$ at birth and became positive for 2A2 and 1F6 from 4 and 8 weeks of age on, respectively. In the pancreatic acini, zymogenic cells showed positive reactions for $\mathrm{KNH}-30$ and $2 \mathrm{~A} 2$ from 4 weeks on and for 1F6 and 6D12 from 8 weeks on and at age 2 years, respectively. Pancreatic islet cells showed positive reactions for $\mathrm{KNH}-30,6 \mathrm{D} 12$, and $2 \mathrm{~A} 2$ from 4 weeks on and for 1F6 from 8 weeks on. In the brain, the ependymal and choroid plexus cells were not reactive for $\mathrm{KNH}-30$ in any age group; however, these cells were positive for the other antibodies from 4 weeks of age on (Fig. 1, D and E). 1F6 immunoreactivity was not expressed in any neuronal cells in any age group. However, positive reactions for $\mathrm{KNH}-30$ (Fig. 1F) and 6D12 were observed in neuronal cells at birth; those for 2A2 were found from 4 weeks on. These results indicate that $C M L$ accumulates in vivo earlier than CEL, 2A2-positive AGE, and fluorolink. 
Table 1. Immunohistochemical Distribution of AGEs in Various Tissues and Cells in Young and Adult Rats Detected by Anti-AGE Monoclonal Antibodies KNH-30, 6D12, 2A2, and 1F6

\begin{tabular}{|c|c|c|c|c|c|c|c|c|c|c|c|c|c|c|c|c|}
\hline \multirow[b]{3}{*}{ Site } & \multicolumn{16}{|c|}{ Immunoreactivity } \\
\hline & \multicolumn{4}{|c|}{ KNH-30 } & \multicolumn{4}{|c|}{$6 \mathrm{D} 12$} & \multicolumn{4}{|c|}{$2 \mathrm{~A} 2$} & \multicolumn{4}{|c|}{$1 \mathrm{~F} 6$} \\
\hline & $0 d$ & $4 w$ & $8 w$ & $2 y$ & $0 d$ & $4 w$ & $8 w$ & $2 y$ & $\mathrm{Od}$ & $4 w$ & $8 w$ & $2 y$ & Od & $4 w$ & $8 w$ & $2 y$ \\
\hline \multicolumn{17}{|l|}{ Heart } \\
\hline Cardiomyocytes & + & + & + & + & + & + & + & + & ++ & ++ & ++ & ++ & \pm & \pm & \pm & + \\
\hline \multicolumn{17}{|l|}{ Lung } \\
\hline Bronchial epithelial cells & + & + & + & + & + & + & + & + & + & + & + & + & + & + & + & + \\
\hline Cartilage cells & + & + & + & + & + & + & + & + & + & + & + & + & + & + & + & + \\
\hline Macrophages & \pm & + & + & + & \pm & + & + & + & \pm & + & + & + & \pm & + & + & + \\
\hline \multicolumn{17}{|l|}{ Liver } \\
\hline Hepatocytes & + & + & + & + & + & + & + & + & - & + & + & + & - & - & + & + \\
\hline Kupffer cells & - & - & - & + & - & - & + & + & - & + & + & + & + & + & + & + \\
\hline \multicolumn{17}{|l|}{ Spleen } \\
\hline Macrophages & + & + & + & + & ++ & ++ & ++ & ++ & + & + & + & + & + & + & + & + \\
\hline \multicolumn{17}{|l|}{ Kidney } \\
\hline Tubular epithelial cells & + & + & + & + & + & + & + & + & + & + & + & + & + & + & + & + \\
\hline Glomerular endothelial cells & - & - & - & + & - & - & - & + & - & - & - & + & - & - & + & + \\
\hline \multicolumn{17}{|l|}{ Stomach } \\
\hline Epithelial cells & + & + & + & + & + & + & + & + & - & + & + & + & - & - & + & + \\
\hline \multicolumn{17}{|l|}{ Intestine } \\
\hline Epithelial cells & + & + & + & + & + & + & + & + & - & + & + & + & - & - & + & + \\
\hline Goblet cells & - & - & - & - & - & - & - & - & - & - & - & - & - & - & - & - \\
\hline \multicolumn{17}{|l|}{ Pancreas } \\
\hline Zymogenic cells & - & + & + & + & - & - & - & + & - & + & + & + & - & - & + & + \\
\hline Islet cells & - & + & + & + & - & + & + & + & - & + & + & + & - & - & + & + \\
\hline \multicolumn{17}{|l|}{ Brain } \\
\hline $\begin{array}{l}\text { Ependymal cells/choroid } \\
\text { plexus }\end{array}$ & - & - & - & - & - & + & + & + & - & + & + & + & - & + & + & + \\
\hline Neuronal cells & ++ & ++ & ++ & ++ & + & + & + & + & - & + & + & + & - & - & - & - \\
\hline
\end{tabular}

++ , intensely positive; +, positive; \pm , weakly positive; -, negative; d, day; w, week; y, years.

Three to five rats in each group were examined.

\section{Immunohistochemical Localization of AGE in STZ-Induced Diabetic Rats}

Table 2 shows the characteristics of rats 20 weeks after initial injection of STZ compared with agematched control rats. The body weight of the STZtreated rats was significantly lower 20 weeks after the initial injection of STZ $(p<0.01)$ and their fasting blood glucose levels were significantly higher $(p<$ 0.01). Other characteristics of diabetes mellitus, such as polydipsia, hyperphagia, and polyuria, were also observed in the STZ-treated rats. Biochemical analysis demonstrated hyperketonemia in serum of STZtreated diabetic rats as shown by prominent increases of acetoacetate, 3-hydroxybutyrate, and total ketone bodies compared with age-matched control rats $(p<$ $0.05, p<0.01$, and $p<0.01$, respectively). The number and diameter of pancreatic islets in STZtreated rats were significantly reduced compared with those in control rats injected with saline-citrate buffer instead of STZ ( $p<0.01$ and $p<0.05$, respectively). Histopathologic examination revealed that a small number of lymphocytes, macrophages, and neutrophils infiltrated around and within the pancreatic islets, associated with destruction of the fundamental islet tissue architecture as well as degeneration and necrosis of $\beta$-cells. Immunohistochemical staining with polyclonal anti-insulin antibody showed a marked reduction in the numbers of insulin-secreting $\beta$-cells in the pancreatic islets of STZ-treated rats $(p<0.1)$. The pancreatic islets of control rats were histologically normal. In the STZ-treated rats, histologic and morphologic changes included accumulation of lipofuscin granules in the hepatocytes, increased number of macrophages in the red pulp of spleen, and reduced size of renal glomeruli, accompanied by mesangial cell proliferation and thickening of the basement membrane. Also, the number of testicular Leydig cells were reduced. These changes were characteristic of diabetes mellitus in STZ-treated rats.

Table 3 shows the immunohistochemical distribution of AGE in various tissues and cells of STZinduced diabetic rats and age-matched control rats. In most organs and tissues of STZ-induced diabetic rats, positive reactivities for the anti-AGE monoclonal antibodies $\mathrm{KNH}-30,6 \mathrm{D} 12,2 \mathrm{~A} 2$, and $1 \mathrm{~F} 6$ were similar to those of the control rats. However, the intensity of immunoreactivity for $\mathrm{KNH}-30$ and 1F6 (Fig. 2A) antibodies in hepatocytes of STZ-induced diabetic rats 


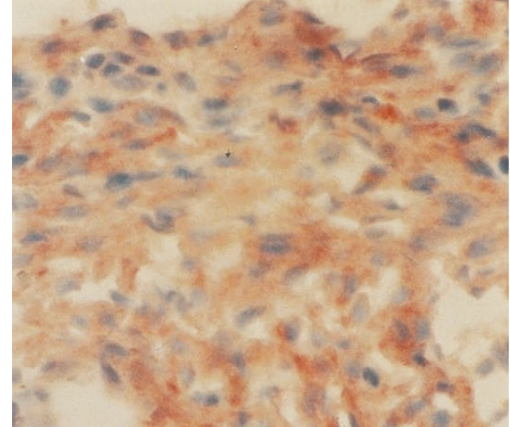

A. 2 A2/Heart/Day 0

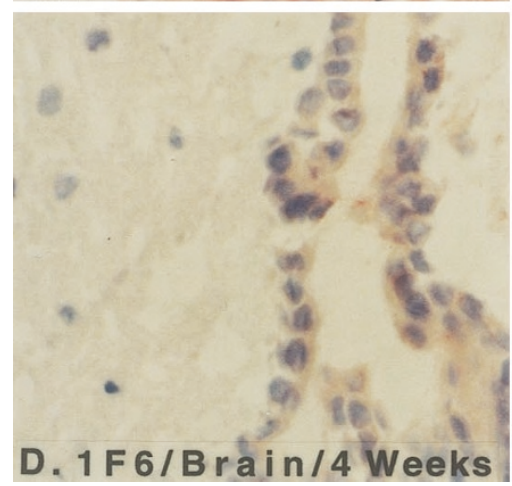

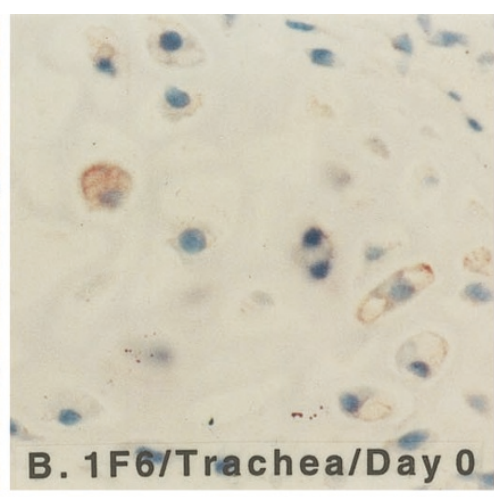
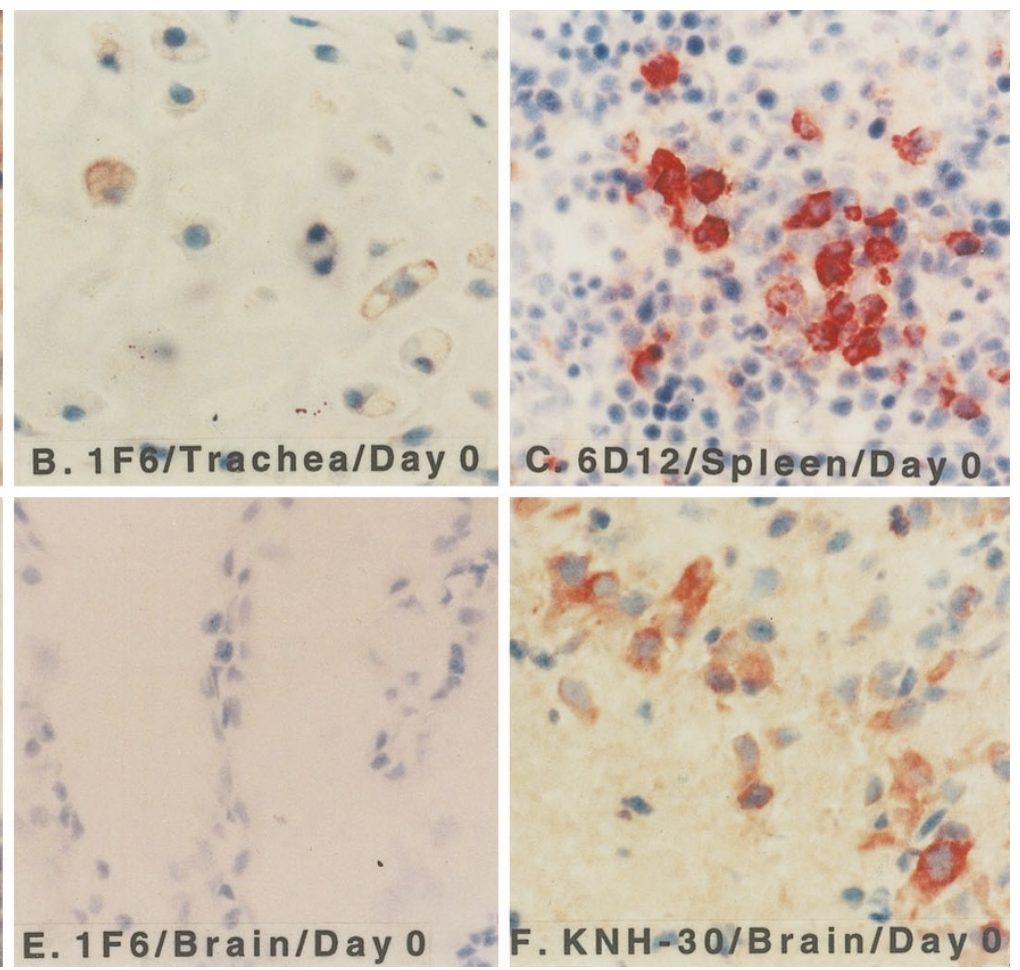

Figure 1.

Immunohistochemical localization of advanced glycation end products (AGE) in representative sections of most organs and tissues of rats at birth (Day 0) and increased with aging. A, Cardiomyocytes showed a positive reaction to $2 A 2$ at Day $0.8,1 F 6$-positive deposits were seen in hyaline cartilage cells in the trachea at Day 0. C, Splenic red pulp macrophages at Day 0 contained 6D12-positive deposits. D and E, Ependymal cells and choroid plexus showed positive reactions for 1F6 at 4 weeks of age (D), but not at Day $0(E)$. F, Neuronal cells in the brain expressed a positive reaction for KNH-30 at Day 0 . The representative sections were selected for the figure, excluding the most intense or weakest immunostaining. Indirect immunoperoxidase method. A to $F$, original magnification, $\times 360$.

Table 2. Characteristics of Rats at 20 Weeks after the Initial Injection of STZ Compared with Age-Matched Control Rats

\begin{tabular}{|c|c|c|}
\hline Variable & STZ-treated rats & Control rats \\
\hline Number of rats examined & 4 & 4 \\
\hline Body weight (g) & $215 \pm 30.3^{\star *}$ & $458 \pm 26.1$ \\
\hline Blood glucose $(\mathrm{mg} / \mathrm{dl})$ & $454 \pm$ & $101 \pm 28.6$ \\
\hline \multicolumn{3}{|l|}{ Ketone bodies $(\mu \mathrm{mol} / \mathrm{l})$} \\
\hline Acetoacetate & $1921 \pm 962^{*}$ & $65 \pm 78$ \\
\hline utyrate & $2825 \pm$ & 501 \\
\hline Total ketone bodies & $4746 \pm$ & 566 \\
\hline \multicolumn{3}{|l|}{ Pancreatic islets } \\
\hline Number $^{a}$ & $0.55 \pm 0.51^{\star *}$ & $2.08 \pm 1.19$ \\
\hline Diameter $(\mu \mathrm{m})$ & $8.91 \pm 3.34^{\star}$ & $16.65 \pm 11.51$ \\
\hline$\beta$-cells ${ }^{b}$ & $2.64 \pm 2.0$ & $71.00 \pm 62.43$ \\
\hline \multicolumn{3}{|c|}{$\begin{array}{l}\text { STZ, streptozotocin. } \\
\text { Data are means } \pm \mathrm{SD} ;{ }^{*} \mathrm{p}<0.05 \text { vs age-matched controls; }{ }^{* *} \mathrm{p}<0.01 \text { vs } \\
\text { ge-matched controls. } \\
{ }^{a} \text { Number of pancreatic islets counted per } 1-\mathrm{mm}^{2} \text { section. } \\
{ }^{b} \text { Number of insulin-positive } \beta \text {-cells per islet. }\end{array}$} \\
\hline
\end{tabular}

was more marked than that of the control rats (Fig. $2 \mathrm{~B})$. Immunoreactivity for $2 \mathrm{~A} 2$ was more intense in macrophages in the spleen of the diabetic rats than in the control rats. Immunoreactivities for 6D12, $\mathrm{KNH}-30$ (Fig. 2, C and D), and 1F6 in renal glomerular endothelial cells and mesangial cells, for 6D12, KNH-30, and 2A2 (Fig. 2, E and F) in testicular Leydig cells, and for 6D12 (Fig. 2, G and H), 1F6, and 2A2 in erythrocytes were more prominent in the diabetic rats than in the control rats. These results suggest that the accumulation of AGE in various tissues result in tissue and cellular injury, which induces the histopathologic changes characteristic of diabetes mellitus.

\section{Immunohistochemical Localization of AGE in Rat Embryos and Fetuses}

Rat fetuses at $10,13,16$, and 19 days of gestation were examined using the anti-AGE monoclonal antibodies $\mathrm{KNH}-30,6 \mathrm{D} 12,2 \mathrm{~A} 2$, and 1F6. At 10 fetal days, positive reactions for $\mathrm{KNH}-30$ (Fig. 3A), 6D12 (Fig. 3C), and $2 \mathrm{~A} 2$ (Fig. 3E) were demonstrated in the ectoderm, mesoderm, and endoderm; however, 1F6 was not detected in any embryos (Fig. 3G). In addition, macrophages and endothelial cells in the placental decidual tissues after 10 days of gestation showed positive reactions for all four anti-AGE monoclonal antibodies (Fig. 3, B, D, F, and H). As shown in Table 4, at 13 fetal days, AGE-positive deposits of different intensities were demonstrated in various rudiments of the principal organs and tissues (Fig. 4, A to $\mathrm{H}$ ) as follows. Positive reactions for all four monoclonal anti-AGE antibodies were found in the marginal and mantle layer cells of the brain and spinal cord, mesenchymal cells, endothelial cells of blood vessels, somites/sclerotomes, cardiomyocytes, and epithelial cells of lung 
Table 3. Immunohistochemical Distribution of AGEs in Various Tissues and Cells of STZ-Induced Diabetic Rats and Age-Matched Control Rats

\begin{tabular}{|c|c|c|c|c|c|c|c|c|}
\hline \multirow[b]{2}{*}{ Cell type } & \multicolumn{4}{|c|}{$\begin{array}{l}\text { STZ-induced diabetic } \\
\text { rats }\end{array}$} & \multicolumn{4}{|c|}{ Control rats } \\
\hline & 6D12 & KNH-30 & $1 F 6$ & $2 \mathrm{~A} 2$ & $6 \mathrm{D} 12$ & KNH-30 & $1 F 6$ & $2 \mathrm{~A} 2$ \\
\hline \multicolumn{9}{|l|}{ Heart } \\
\hline Cardiomyocytes & + & + & + & + & + & + & + & + \\
\hline Cartilage cells & + & + & + & + & + & + & + & + \\
\hline Macrophages & + & + & + & + & + & + & + & + \\
\hline \multicolumn{9}{|l|}{ Liver } \\
\hline Hepatocytes & + & ++ & ++ & + & + & \pm & + & + \\
\hline Kupffer cells & \pm & \pm & + & + & \pm & \pm & + & + \\
\hline \multicolumn{9}{|l|}{ Spleen } \\
\hline Macrophages & + & + & ++ & ++ & + & + & ++ & + \\
\hline \multicolumn{9}{|l|}{ Kidney } \\
\hline Tubular epithelial cells & + & + & + & + & + & + & + & + \\
\hline Glomerular endothelial cells & & & ++ & + & \pm & + & + & + \\
\hline \multicolumn{9}{|l|}{ Stomach } \\
\hline Epithelial cells & + & + & + & + & + & + & + & + \\
\hline \multicolumn{9}{|l|}{ Intestine } \\
\hline Epithelial cells & + & + & + & + & + & + & + & + \\
\hline \multicolumn{9}{|l|}{ Testis } \\
\hline Spermatogenic cells & + & + & + & + & + & + & + & + \\
\hline Leydig cells & 7 & $\oplus$ & + & 1 & + & \pm & + & + \\
\hline \multicolumn{9}{|l|}{ Brain } \\
\hline Neuronal cells & + & + & + & + & + & + & + & + \\
\hline \multicolumn{9}{|l|}{ Salivary glands } \\
\hline Epithelial cells & + & + & + & + & + & + & + & + \\
\hline \multicolumn{9}{|l|}{ Thymus } \\
\hline Epithelial reticular cells & + & + & + & + & + & + & + & + \\
\hline \multicolumn{9}{|l|}{ Pancreas } \\
\hline Acinic cells & + & + & + & + & + & + & + & + \\
\hline Islet cells & + & + & + & + & + & + & + & + \\
\hline \multicolumn{9}{|l|}{ Thyroid } \\
\hline Follicular cells & + & + & + & + & + & + & + & + \\
\hline Erythrocytes & ++ & + & $\oplus$ & $\oplus$ & \pm & + & \pm & \pm \\
\hline
\end{tabular}

++ , intensely positive; + , positive; \pm , weakly positive; - , negative.

O: immunoreactivity for each monoclonal anti-AGE antibody is more intense in the tissues or cells of STZ-induced diabetic rats than in those of age-matched control rats. Four rats in each group were examined.

buds. In the anlagen of vibrissae, immunoreaction was shown for $\mathrm{KNH}-30$, but not for the other anti-AGE antibodies. No positive reactions were found for $\mathrm{KNH}-30$ in the fetal liver; for $2 \mathrm{~A} 2$ in the ependymal layer of the fetal brain; or for 1F6 in the epidermis, oral epithelium, nasal placode, cephalic ganglia, kidneys, and gastrointestinal tract. However, the content of AGE was slightly increased from 16 fetal days on, except that the immunoreactivity for 6D12 was unchanged during fetal development. From 16 fetal days on, positive reactions for $\mathrm{KNH}-30$ were seen in the liver; for 2A2 in the anlagen of vibrissae and ependymal layer of rat fetuses. From 19 fetal days on, 1F6 was detected further in the epidermis, oral epithelium, nasal placode, and kidneys. In all fetuses, 6D12 (ie, $\mathrm{CML}$ ) had a wider distribution than did $\mathrm{KNH}-30$ (ie, CEL), 2A2-positive AGE, and fluorolink; CEL, 2A2positive AGE, and fluorolink accumulated in fetal rat tissues, in that order, after the initial emergence of CML.

\section{HPLC Analysis}

Samples from rat fetuses at 13 fetal days revealed an obvious CML (6D12) peak, with the identity of CML confirmed by coelution with a CML standard. The relative amount of $\mathrm{CML}$ was quantitated at $724.8 \pm$ $87.3 \mathrm{mmol} / \mathrm{mol}$ lysine (Fig. 5). Because the lungs showed a more intense immunohistochemical reaction for 6D12 than did the other organs (data not shown), we chose the lungs as a postnatal reference for HPLC. As a result, a small CML peak $(56.7 \pm 1.0$ $\mathrm{mmol} / \mathrm{mol}$ lysine) was also found in the lungs of rats at 28 weeks of age (Fig. 6).

\section{Discussion}

For the four monoclonal antibodies used in the present study-6D12, KNH-30, 1F6, and 2A2-epitopes of the first three recognize CML, CEL, and fluorolink, respectively. Although the epitope of 2A2 has not been deter- 

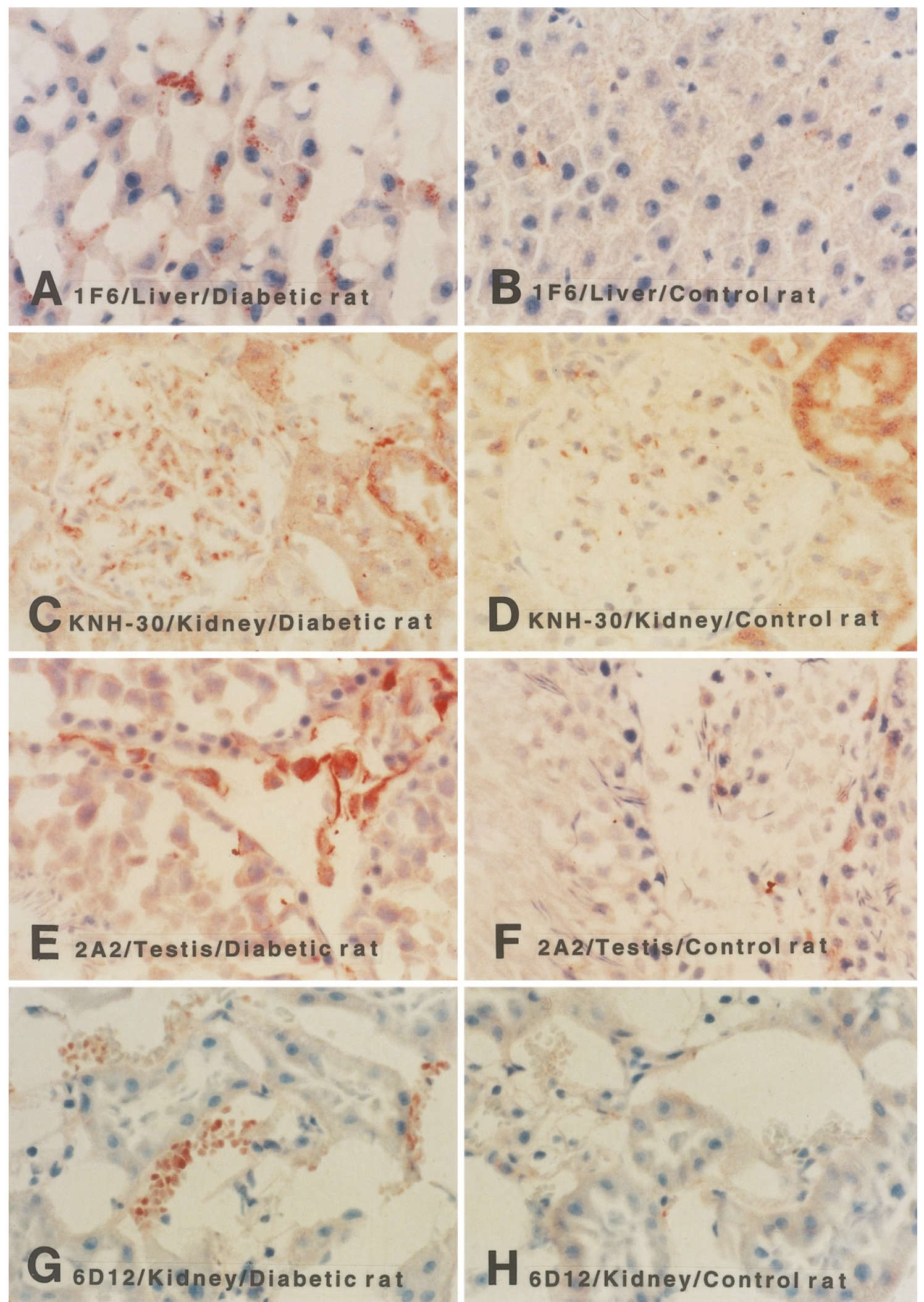

Figure 2.

Immunohistochemical localization of AGE in the representative sections of STZ-induced diabetic rats and age-matched control rats. Hepatocytes in diabetic rats (A) showed a more intense 1F6-positive reaction than those in control rats (B). In renal glomeruli, the KNH-30-positive reaction was more marked in diabetic rats (C) than in control rats (D). Testicular Leydig cells in diabetic rats (E) showed a more marked 2A2-positive reaction than those in control rats (F). In vessels of the kidney, erythrocytes showed a clearer positive reaction for $6 \mathrm{D} 12$ in the diabetic rats $(\mathrm{G})$ than in the control rats $(\mathrm{H})$. When representative sections were selected for the figure, those exhibiting the most intense and the weakest immunostaining were excluded. Immunostaining was performed by the indirect immunoperoxidase method. A to $\mathrm{H}$, original magnification, $\times 360$. 

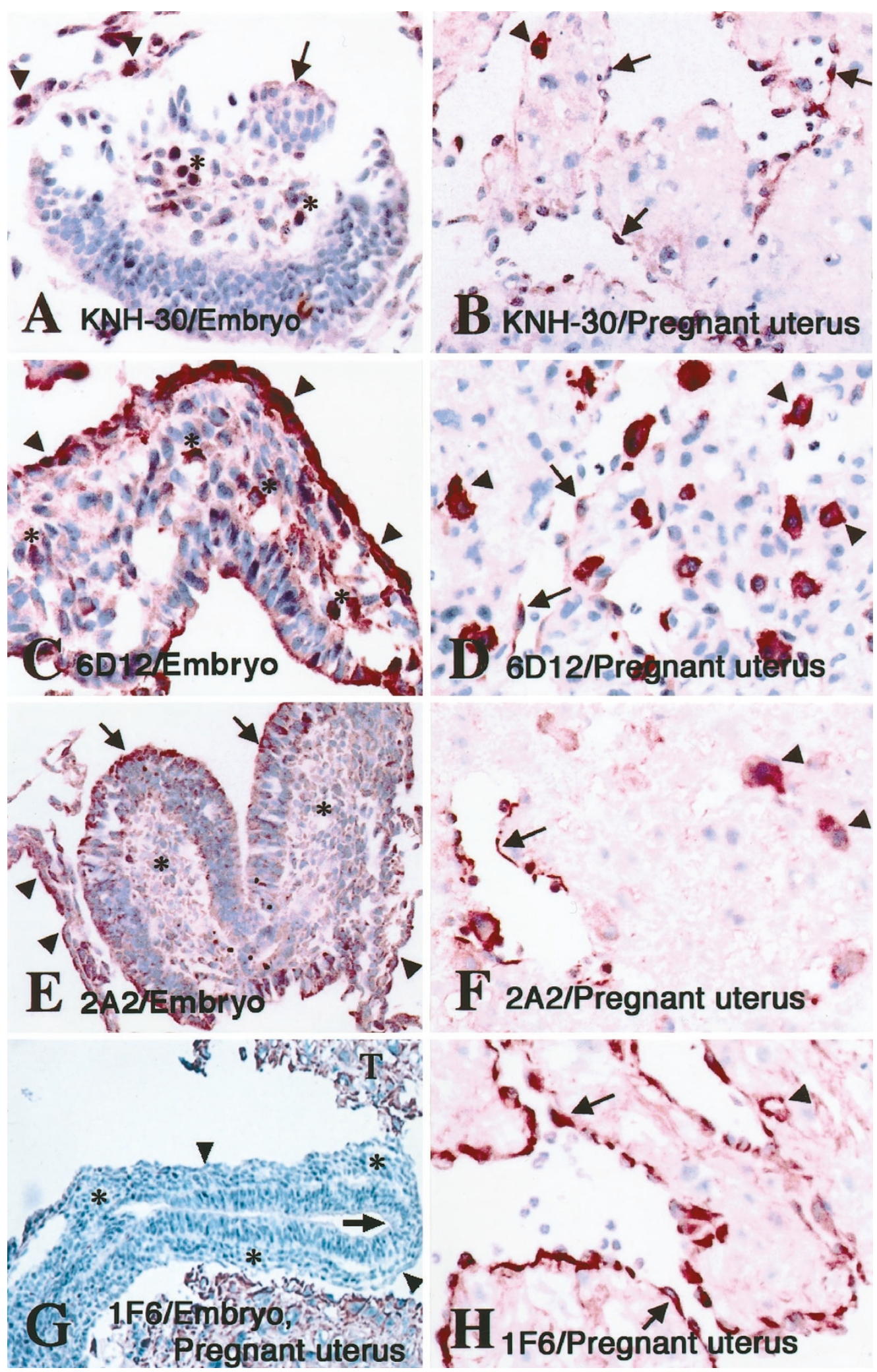

Figure 3.

Immunohistochemical localization of AGE in the representative sections of rat embryos and uteri of the host at the 10th gestational day. KNH-30 (ie, $N^{\epsilon}$-(carboxyethyl)lysine [CEL]) (A and B), $6 \mathrm{D} 12$ (ie, $N^{\epsilon}$-(carboxymethyl)lysine [CML]) (C and D), and 2A2-positive AGE (E and F) were found in the ectoderm (arrows) mesoderm (asterisks), and endoderm (arrowheads) of the embryos (A, C, and E) as well as in macrophages (arrowheads) and vascular endothelial cells (arrows) of the host uteri (B, D, and F). 1F6-positive material, fluorolink, was not found in embryos $(G)$, but it was localized in trophoblasts $(G, T)$, macrophages $(H$, arrowheads), and vascular endothelial cells ( $\mathrm{H}$, arrows) of the pregnant uterus. When representative sections were selected for the figure, those exhibiting the most intense and the weakest immunostaining were excluded. Immunostaining was performed by the indirect immunoperoxidase method. Original magnification: A, $\times 295$; $B, \times 273 ; C$ and $D, \times 384 ; E, \times 169 ; F, \times 425 ; G, \times 76 ; H, \times 390$. 
Table 4. Immunohistochemical Localization of AGEs in Rat Fetuses at 13, 16, and 19 Fetal Days

\begin{tabular}{|c|c|c|c|c|c|c|c|c|c|c|c|c|}
\hline \multirow[b]{2}{*}{ Location } & \multicolumn{3}{|c|}{$6 \mathrm{D} 12$} & \multicolumn{3}{|c|}{ KNH-30 } & \multicolumn{3}{|c|}{$2 \mathrm{~A} 2$} & \multicolumn{3}{|c|}{$1 \mathrm{~F} 6$} \\
\hline & 13 & 16 & 19 & 13 & 16 & 19 & 13 & 16 & 19 & 13 & 16 & 19 \\
\hline \multicolumn{13}{|l|}{ Ectoderm } \\
\hline Epidermis & + & + & + & + & + & + & + & + & + & - & - & \pm \\
\hline Oral epithelium & + & + & + & + & + & + & + & + & + & - & - & + \\
\hline Nasal placode & + & + & + & + & + & + & + & + & + & - & - & + \\
\hline Anlagen of vibrissae & - & - & - & + & + & + & - & \pm & + & - & - & - \\
\hline \multicolumn{13}{|l|}{ Encephalon } \\
\hline Marginal layer & + & + & + & ++ & ++ & ++ & + & + & + & + & + & + \\
\hline Mantle layer & + & + & + & ++ & ++ & ++ & + & + & + & + & + & + \\
\hline Ependymal layer & + & + & + & ++ & ++ & ++ & - & + & + & + & + & + \\
\hline Spinal cord & + & + & + & ++ & ++ & ++ & + & + & + & + & + & + \\
\hline Cephalic ganglia & + & + & + & ++ & ++ & ++ & + & + & + & - & - & - \\
\hline \multicolumn{13}{|l|}{ Mesoderm } \\
\hline Mesenchymal cells & + & + & + & + & + & + & + & + & + & + & + & + \\
\hline Blood vessels & + & + & + & + & + & + & + & + & + & + & + & + \\
\hline Somites/sclerotomes & + & + & + & + & + & + & + & + & + & + & + & + \\
\hline Heart & + & + & + & \pm & + & + & ++ & ++ & ++ & + & + & + \\
\hline Kidney & + & + & + & \pm & + & + & \pm & + & + & - & - & + \\
\hline \multicolumn{13}{|l|}{ Endoderm } \\
\hline Liver & + & + & + & - & + & + & \pm & + & + & + & + & + \\
\hline Lung & + & + & + & + & + & + & + & + & + & ++ & ++ & ++ \\
\hline Gastrointestinal tract & ++ & ++ & ++ & + & + & + & + & + & + & - & - & - \\
\hline
\end{tabular}

++ , intensely positive; + , positive; \pm , weakly positive; - , negative; $13,16,19$ : fetal days 13,16 , and 19

Four rats in each group were examined.

mined, this monoclonal antibody seems to recognize an AGE antigen different from CML, CEL, fluorolink, and other known AGE-specific molecules such as pyrraline, pentosidine, and cross-lines. AGE-specific molecules are classified into two groups on the basis of their chemical structures: fluorescent and cross-linked (fluorescent/cross-linked) and nonfluorescent and noncross-linked (nonfluorescent/noncross-linked) (Ikeda et al, 1996; Obayashi et al, 1996). Fluorolink belongs to the former group, CML and CEL to the latter group (Ahmed et al, 1997; Horiuchi et al, 1996; Wells-Knecht et al, 1996).

This immunohistochemical investigation revealed that the intensities of immunoreactivity for the antiAGE monoclonal antibodies varied in the different organs and tissues of adult rats, in agreement with our previous report of results in humans (Ling et al, 1998). In four groups of rats of different ages, AGE-specific molecules accumulated during aging, although the molecules varied in time of emergence and distribution. In rats at birth, all four AGE-specific molecules were found in cardiomyocytes, bronchial epithelial cells, cartilage cells, alveolar macrophages, splenic macrophages, and urinary tubular epithelial cells. In addition, CML and CEL were found in hepatocytes, epithelial cells of the gastrointestinal tract, and neuronal cells, and fluorolink was detected in Kupffer cells. From 4 weeks of age on, CEL was deposited in pancreatic acinic and islet cells; CML, in pancreatic islet cells and in ependymal and choroid plexus cells of the brain; 2A2-positive AGE antigen, in hepatocytes, Kupffer cells, epithelial cells of the gastrointes- tinal tract, pancreatic acinic and islet cells, ependymal cells, choroid plexus cells, and neuronal cells of the brain; and fluorolink, in ependymal and choroid plexus cells of the brain. From 8 weeks of age on, CML was further demonstrated in Kupffer cells, and fluorolink was found in hepatocytes, glomerular endothelial cells, epithelial cells of gastrointestinal tract, and pancreatic acinic and islet cells. At 2 years of age, CEL was seen in Kupffer cells and renal glomerular endothelial cells; CML and 2A2-positive AGE antigen, in renal glomerular endothelial cells. CML, CEL, fluorolink, and 2A2-positive molecules were not observed in goblet cells in the intestinal mucosa; CEL was not found in ependymal and choroid plexus cells of the brain; and fluorolink did not accumulate in neuronal cells of the brain. These results show that AGE accumulate in various organs and tissues of rats, that their accumulation increases with aging, and that AGE formation is heterogeneous in the different tissues and cell types. Among the four AGE-specific molecules, CML was found earlier and was more widely distributed than CEL. Subsequently, 2A2positive AGE antigen and fluorolink were detected. These results suggest that $\mathrm{CML}$, one of the nonfluorescent/noncross-linked AGE, is produced earlier in tissues than is fluorolink, a fluorescent/crosslinked AGE.

AGE accumulation in tissues gradually increases with aging and is accelerated in diabetes mellitus (Brownlee et al, 1988). Previous studies have shown the accumulation of AGE in various tissues and cell types during diabetic complications (Berg et al, 1997; 

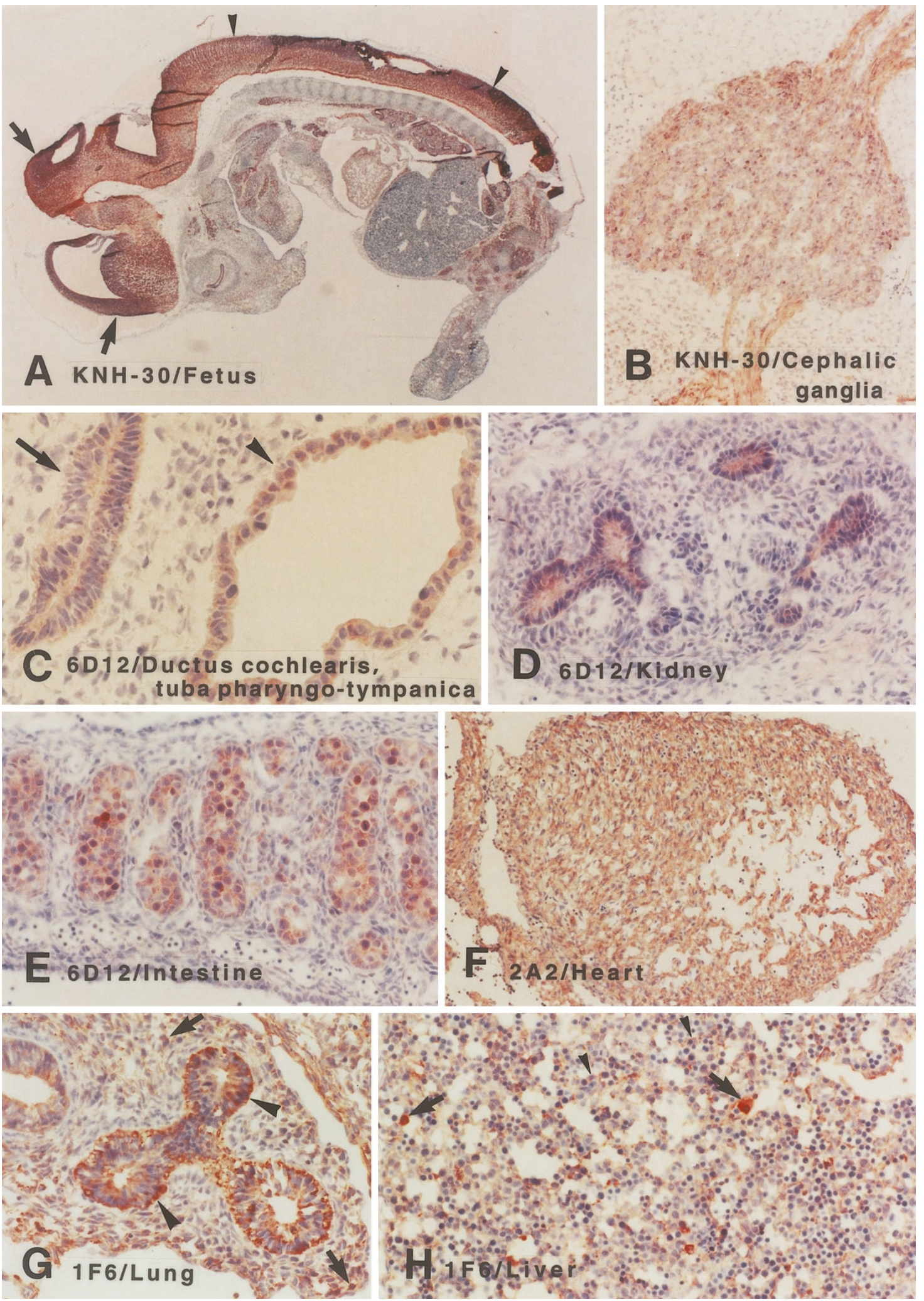

\section{Figure 4.}

Immunohistochemical localization of AGE in the representative sections of rat fetuses at 13 fetal days. A KNH-30-positive reaction was found in the nervous system, especially in the brain (A, arrows), spinal cord (A, arrowheads), and cephalic ganglia (B). The 6D12-positive reaction was marked in the epithelial cells of ductus cochlearis (C, arrow), tuba pharyngo-tympanica (C, arrowhead), kidney (D), and intestine (E). Cardiomyocytes showed a 2A2-positive reaction ( $\mathrm{F}$ ). In the lungs, 1F6-positive reaction was found weakly in the mesenchymal cells (G, arrows) and intensely in the epithelial cells (G, arrowheads). In the liver, 1F6-positive reactivity demonstrated weakly in hepatocytes $(\mathrm{H}$, arrowheads) and markedly in macrophages $(\mathrm{H}$, arrows). When representative sections were selected for the figure, those exhibiting the most intense and the weakest immunostaining were excluded. Immunostaining was performed by the indirect immunoperoxidase method. Original magnification: $A, \times 9$; B and $F, \times 90 ; C, \times 288 ; D, E, G$, and $H, \times 180$. 
A. CML standard

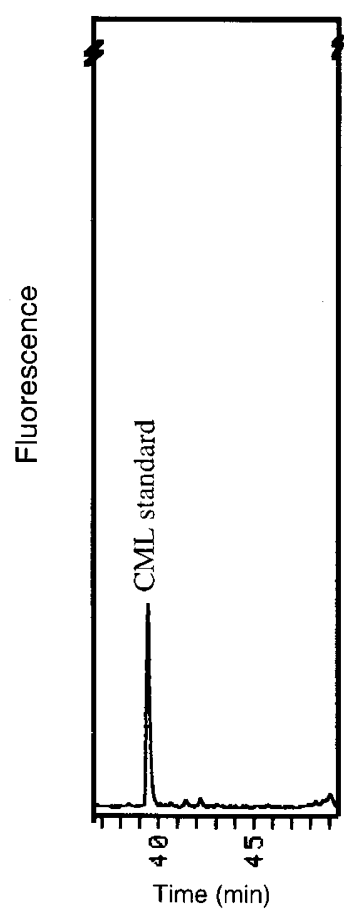

B. Fetal samples

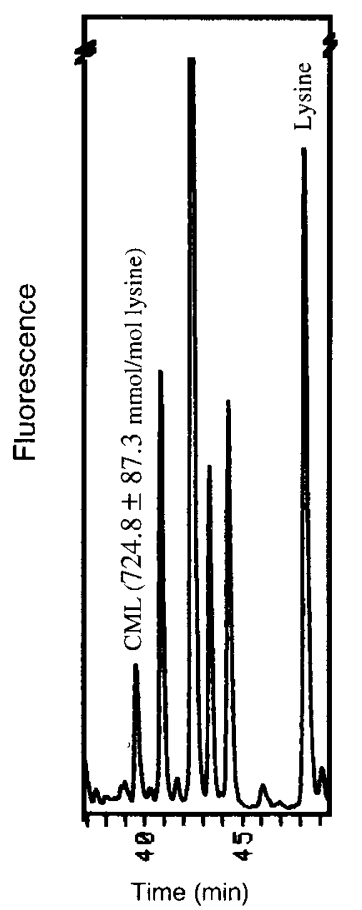

C. Fetal CML samples ${ }^{+}$standard

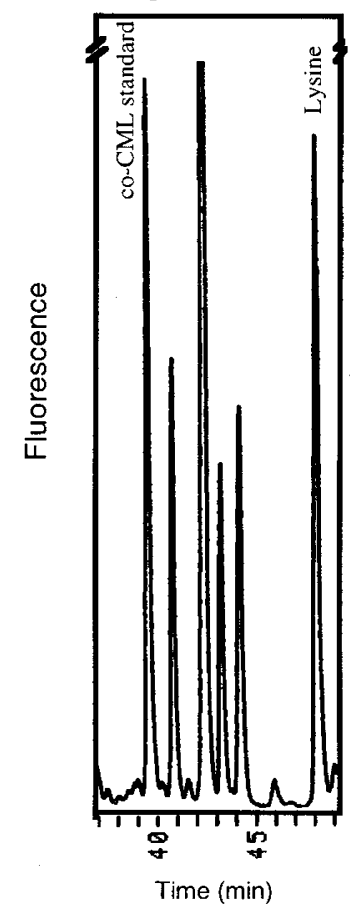

Figure 5.

Detection of CML in rat fetuses at 13 fetal days by RP-HPLC. Hydrolysis and derivation were as described in "Materials and Methods." A, A CML standard (100 pmol) peak was found at 39.5 minutes. B, In fetal rat samples (11.2 pmol protein), a peak was also found at 39.5 minutes. C, Coelution of fetal rat samples (11.2 pmol protein) and CML standard $(200 \mathrm{pmol})$ revealed only a higher peak at 39.5 minutes (but not the other peaks) compared with peaks found in (B). The CML in fetal rat samples (B) was normalized as $724.8 \pm 87.3 \mathrm{mmol} / \mathrm{mol}$ lysine.

A. 28-week-old lungs

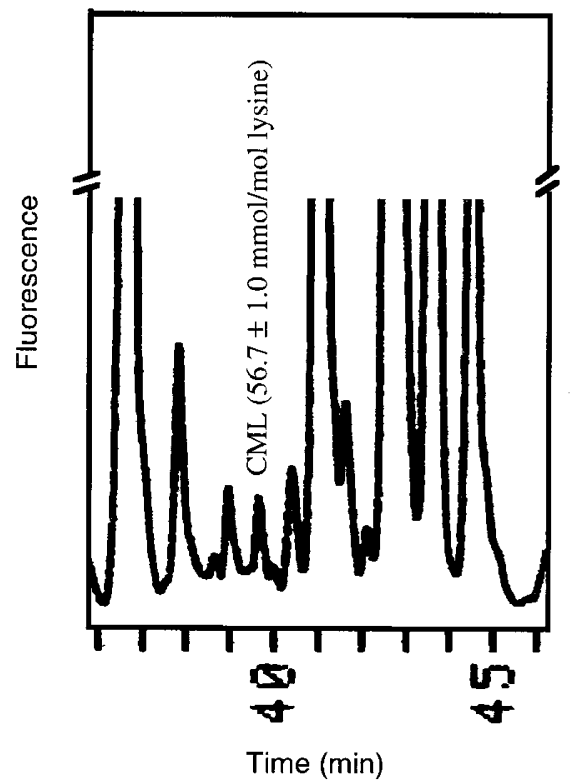

B. 28-week-old lungs + CML standard

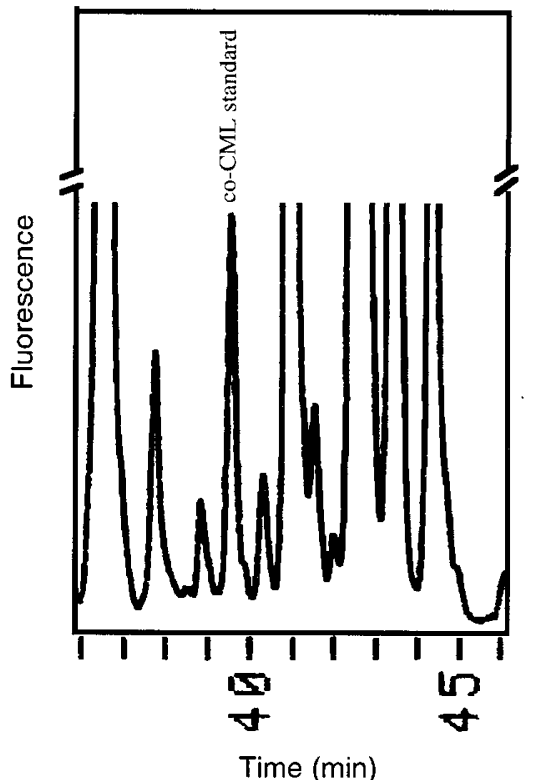

Figure 6.

Detection of CML in rat lungs by RP-HPLC. Hydrolysis and derivation were as described in "Materials and Methods." In the lungs of 28 -week-old rats (48 pmol protein), a small peak was found at 39.5 minutes (A). The peak was confirmed as CML by coinjection with CML standard (100 pmol) (B). CML in the lungs was normalized as $56.7 \pm 1.0 \mathrm{mmol} / \mathrm{mol}$ lysine.

Bucala et al, 1993; Hashimoto, 1998; Nakayama et al, 1993; Sakai et al, 1996; Schmidt et al, 1996; Seftel et al, 1997; Stitt et al, 1998); however, these studies did not systematically examine the accumulation and distribution of AGE in tissues. To experimentally elucidate the process of AGE accumulation in tissues, we used 
immunohistochemical methods to study various organs and tissues of STZ-induced diabetic rats. Because STZ is cytotoxic to $\beta$-cells in pancreatic islets, it has been used to produce diabetes mellitus in experimental animal models (Karasik and Hattori, 1994; Like and Rossini, 1976). Our study in STZ-injected rats demonstrated a statistically significant reduction in the number of $\beta$-cells in pancreatic islets $(p<0.01)$, fasting hyperglycemia, weight loss, polyuria, polydipsia, and polyphagia, all of which are characteristics of diabetes mellitus (Karasik and Hattori, 1994). STZinduced diabetic rats also showed accumulation of lipofuscin granules in hepatocytes, increased numbers of macrophages in splenic red pulp, renal glomerular damage accompanied by mesangial cell proliferation and basement membrane thickening, and decreased numbers of testicular Leydig cells.

Immunohistochemically, positive immunoreactivities for the four antibodies in most organs and tissues of the diabetic rats were similar to those in agematched control rats, and the antibody distribution patterns were also not essentially different. However, more intense accumulation in STZ-induced diabetic rats compared with age-matched control rats was seen for CEL and fluorolink in hepatocytes; 2A2positive AGE antigen in splenic macrophages; CML, CEL, and fluorolink in renal glomerular endothelial and mesangial cells; CML and CEL in testicular Leydig cells; and CML, fluorolink, and 2A2-positive AGE antigen in erythrocytes. These results suggest that marked accumulation of AGE in these tissues and cells is responsible for the characteristic histopathologic changes of diabetes mellitus, in agreement with findings reported previously (Jobst and Lakatos, 1996; Orth et al, 1979; Paz and Homonnai, 1979; Vlassara et al, 1994; Wautier et al, 1994).

In diabetes, AGE are formed, deposited, and metabolized actively. Although AGE products (AGEmodified proteins) are known to be degraded and cleared by the liver (Smedsrød et al, 1997), kidneys (Dolhofer-Bliesener et al, 1995), and macrophages (Mori et al, 1995; Suzuki et al, 1997), the excessive accumulation of AGE in these tissues and cells induces tissue injury in diabetes mellitus by decreasing solubility of tissue proteins (Schnider and Kohn, 1981), by giving rise to oxidative stress in these tissues (Fu et al, 1998), and by allowing cells to interact with AGE via AGE receptors (Katsuoka et al, 1997; Suzuki et al, 1997; Vlassara et al, 1995). Macrophages are the main degradation sites of AGE taken up via macrophage scavenger receptors and the other AGE receptor systems, and they release small trichloroacetic acidsoluble AGE peptides. Extracellular proteolysis of matrix components, however, gives rise to fragments, and the components contain variable amounts of AGE moieties. These degradation products of AGEcontaining proteins are presumably released into the peripheral circulation and are cleared by the kidneys, where arteries and glomeruli accumulate excessive amounts of AGE, leading to vascular and renal dysfunction (Vlassara et al, 1994). In the present study, AGE accumulated in hepatocytes, accompanied by accumulation of lipofuscin pigments. In the liver of diabetic patients, histones contain AGE, which might be lipofuscin pigments (Jobst and Lakatos, 1996). Studies reported that STZ-induced diabetic rats are infertile, presumably because of decreased testicular Leydig cell function and altered Leydig cell components (Paz and Homonnai, 1979; Orth et al, 1979). In the present study, we found excessive accumulation of AGE in and numerical reduction of testicular Leydig cells. This suggests that the reduction in the number of testicular Leydig cells results from cell injuries caused by the excessive AGE accumulation, leading to Leydig cell dysfunction, a cause of infertility of male diabetic rats. AGE formation in erythrocytes, especially in surface membrane proteins, induces the functional abnormalities of erythrocytes, which show reduced deformability and lowered membrane fluidity (Wautier et al, 1994). AGE on the surface of erythrocytes in diabetic rats can also function as ligands that interact with various receptors for AGE on endothelial cells and result in injury to the endothelial cells. Thus, AGE might be important for the development of vascular complications. All these results suggest that the hyperglycemia of diabetes accelerates the accumulation of AGE in vivo and that excessive accumulation of AGE results in pathologic changes in tissues and cells, especially in the liver, kidneys, testes, macrophages, and erythrocytes.

As well as hyperglycemia, ketosis/acidosis is a major complication of diabetes mellitus; the current study demonstrated prominent hyperketonemia in STZ-induced diabetic rats at 20 weeks after initial injection of STZ. This complication seems to be an important enhancing and accelerating factor for endogenous AGE formation, because hyperketonemia in type I diabetic patients is known to enhance nitric oxide (NO) release from endothelial cells (Avogaro et al, 1999), oxygen radical formation and lipid peroxidation (Jain et al, 1998), and a decrease in intracellular glutathione levels in erythrocytes (Jain and McVie, 1999). Our recent preliminary in vitro study demonstrated that $\mathrm{NO}$ has an enhancing effect for AGE formation (unpublished data), suggesting that the increased NO production in the STZ-induced diabetic rats is involved in the acceleration of AGE formation. In addition, excessive oxygen radical formation induced by hyperketonemia in diabetes mellitus seems to result in lipid peroxidation (Jain and McVie, 1999), a mechanism of oxidation responsible for AGE formation (Nagai et al, 1997). Because degradation of methylglyoxal into D-lactate through glyoxalase degradation system is impaired by a hyperketonemia-induced decrease in glutathione and glyoxalase I, amounts of methylglyoxal increase to form AGE, including CEL. In addition, levels of glyoxal might be increased because of impairment of the glyoxalase degradation system in hyperketonemia involved in AGE formation, because increased reaction of glyoxal with proteins can induce CML formation (Degenhardt et al, 1998). Through these various mechanisms, hyperketonemia seems to enhance and accelerate the endogenous AGE production in the tissues of STZ-induced diabetic rats. 
The present study also demonstrated the accumulation of the four AGE-specific molecules in rat fetuses from the early stage of ontogeny. Except for fluorolink, the other three AGE-specific molecules (CML, CEL, and 2A2-positive AGE antigen) were found in all ecto-, meso-, and endodermal tissues at 10 fetal days. The AGE deposits tended to increase in the various fetal tissues and cells with progression of fetal development. To confirm the accumulation of AGE in rat fetuses, we performed HPLC to quantify a dominant AGE structure, CML, in tissue proteins (lkeda et al, 1996; Reddy et al, 1995). CML content was $724.8 \pm$ $87.3 \mathrm{mmol} / \mathrm{mol}$ lysine in rat fetuses at 13 fetal days and $56.7 \pm 1.0 \mathrm{mmol} / \mathrm{mol}$ lysine in the lungs of 28-week-old rats, the lungs being tissues that showed more intense immunoreactivity for 6D12 than did other organs and tissues (not shown). These data verified that AGE accumulation occurs not only in postnatal and adult life but also from the early stage of ontogeny, and also that AGE accumulation in rat fetuses is more marked than in adult rats. Although quantification of CML by HPLC was carried out in the present investigation, the HPLC quantification of other AGEspecific molecules and its relationship to the immunohistochemical accumulation of AGE-modified proteins in the embryonic and prenatal stages are an intriguing problem that we should clarify in subsequent studies.

Two possible interpretations must be considered for the AGE accumulation in embryonic and fetal rat tissues. One possibility is that some of the AGE that accumulate in the fetuses comes via the blood stream from the maternal side, because AGE are found in human serum and urine (Dolhofer-Bliesener et al, 1995; Mitsuhashi et al, 1997; Munch et al, 1997; Robert and Jonathan, 1983). Although embryos and fetuses are connected to their mothers through the placentas, maternal blood is separated from the fetal blood stream by the placental barrier, tissues consisting of the syncytial membrane and trophoblasts, the stromal cells of the chorionic villi, and the basement membrane and endothelial cells of the fetal capillaries. The fetoplacental membrane functions in the fetalmaternal exchange of gases, nutrients, and metabolites. Thus, AGE-albumin or other serum AGE proteins might be transferred as serum components through the placenta into the embryos or fetuses. Competitive enzyme-linked immunosorbent assay has shown that serum levels of AGE are higher in diabetic patients than in healthy individuals (Berg et al, 1997). Chromatographic assays disclosed that $10 \%$ to $12 \%$ of normal human serum albumin is nonenzymatically glycosylated (Robert and Jonathan, 1983). In rats, glycated albumin is also found in normal serum (Layton and Jerums, 1988). In uterine decidual tissues of pregnant rats, we found marked accumulation of AGE-specific molecules in macrophages and vascular endothelial cells. In the present study, however, we did not detect fluorolink in rat fetuses at 10 fetal days, although we did find it in some cell types from 13 fetal days on. In addition, RP-HPLC showed that the CML concentration was higher in rat fetuses than in pulmonary tissues of adult rats. These results suggest an- other possibility: that AGE are endogenously generated in rat embryos and fetuses. In fetal rat tissues, $\mathrm{CML}$ accumulated in more locations and earlier than did CEL, 2A2-specific molecule, and fluorolink, and these other molecules were deposited, in that order, during the progression of ontogeny. These data suggest that nonfluorescent/noncross-linked AGE are formed and deposited earlier than are fluorescent/ cross-linked AGE and that the latter are produced during the late stage of ontogeny.

In conclusion, four AGE-specific molecules-CML, CEL, 2A2-positive AGE, and fluorolink-accumulate in rats not only in postnatal and adult life but also from an early stage of ontogeny. The distribution and accumulation of AGE increase during the aging process. Hyperglycemia and hyperketonemia in diabetes mellitus accelerate the accumulation of AGE in vivo to induce pathologic changes characteristic of the disease.

\section{Materials and Methods}

\section{Animals}

Wistar rats were purchased from SLC Company (Hamamatsu, Japan). To obtain rat fetuses, 3-monthold Wistar rats were bred (one night of mating). Pregnancy was determined by the presence of vaginal plugs. On Days 10, 13, 16, and 19 of gestation, fetuses were removed from the uteri of the pregnant rats. Rats were killed under ether anesthesia at birth, 4 weeks, 8 weeks, and 2 years of age.

Eight-week-old male rats (weighing $242.8 \pm 4.4 \mathrm{~g}$ ) were randomly divided into STZ-treated and agematched control group. We produced diabetes mellitus by intravenous injections of $45 \mathrm{mg}$ of STZ (Sigma Chemical, St. Louis, Missouri) in $200 \mu$ l of $0.05 \mathrm{M}$ saline-citrate buffer $(\mathrm{pH} 4.5)$ per kilogram of body weight and then $25 \mathrm{mg}$ of STZ per kilogram of body weight a week after the initial injection. Age-matched control rats received intravenous injections of $200 \mu \mathrm{l}$ of $0.05 \mathrm{M}$ saline-citrate buffer $(\mathrm{pH} 4.5)$ alone. The animals were killed under ether anesthesia 20 weeks after the initial injection. Blood samples were collected into tubes containing EDTA. Plasma and serum were obtained by centrifugation at $1000 \times g$ for 10 minutes at $4^{\circ} \mathrm{C}$. Blood glucose levels were measured in diabetic and control rats by the Mutarodase-glucose oxidase method (Wako Pure Chemical Industries, Osaka, Japan). Ketone bodies including acetoacetate, 3-hydroxybutyrate, and total ketone bodies were analyzed by the enzymatic cycling method, according to the instruction of the Special Reference Laboratories (SRL, Tokyo, Japan). Animal care and treatment adhered to the guidelines of the Center for Animal Resources and Development of Kumamoto University for the care and use of laboratory animals. Three to five animals were used for each experiment.

\section{Tissue Preparation}

From adult rats, three or more specimens were removed from large organs such as lungs, liver, kidneys, 
and heart and small organs or tissues, such as pancreas and spleen, were used as a specimen. For immunohistochemical analysis, tissue samples from all rats were fixed with $2 \%$ periodate-lysineparaformaldehyde at $4^{\circ} \mathrm{C}$ for 6 hours and were washed with PBS (pH 7.2) containing a graded series of sucrose concentrations (10\%, $15 \%$, or $20 \%)$. After immersion in PBS containing 10\% glycerol and $20 \%$ sucrose to inhibit ice crystal formation, the tissues were embedded in OCT compound (Sakura Fine Technical, Tokyo, Japan), frozen in liquid nitrogen, and stored at $-80^{\circ} \mathrm{C}$ until use. Sections were cut $5 \mu \mathrm{m}$ thick with a cryostat MICROM (HM-500M; Walldorf, Germany) and were mounted on poly-L-lysine-coated slides. Frozen cryostat sections were also prepared from unfixed tissue specimens.

For RP-HPLC, rat fetuses at 13 fetal days and the lungs from 28-week-old adult rats were used. Rat fetuses and adult rat lungs were minced, washed three times in cold PBS, and were delipidized with chloroform and methanol (2:1, vol/vol) by mild shaking overnight. The solvent was removed by suction, and pellets were washed sequentially with methanol, deionized water, and PBS, three times with each. Because collagenase used for radioimmunoassay in our laboratory contains AGE (not shown), we did not use collagenase for digestion of tissues. After pellets were homogenized in PBS containing the surfactant $1 \%$ Triton $\times 100$, they were centrifuged at $8000 \times g$ for 15 minutes at $4^{\circ} \mathrm{C}$ (Mitsuhashi et al, 1993). The protein concentration of the supernatant was measured by the bicinchoninic acid assay, with BSA as the standard (Pierce, Rockford, Illinois) (Smith et al, 1985; Wiechelman et al, 1988). Homogenized samples $(70-200 \mu \mathrm{g})$ were hydrolyzed in $6 \mathrm{~N} \mathrm{HCl}$ containing $0.05 \%$ 2-mercaptoethanol at $110^{\circ} \mathrm{C}$ for 24 hours. After $\mathrm{HCl}$ was removed by evaporation, the amino acids were resolubilized with $500 \mu$ l of $20 \mathrm{~mm} \mathrm{HCl}$, $10 \mu \mathrm{l}$ of the volume was mixed with $20 \mu \mathrm{l}$ of $10 \mathrm{~mm}$ 6-aminoquinolyl-N-hydroxysuccinimidyl carbamate (Waters, Tokyo, Japan) in the presence of $70 \mu$ l of borate buffer (0.2 M, pH 8.8) (Cohen and Michaud, 1993).

\section{Monoclonal Antibodies}

Four anti-AGE monoclonal antibodies-6D12, KNH$30,2 A 2$, and $1 F 6$ - were used for the present studies (Fig. 7). 6D12 was produced by immunizing BALB/c mice with AGE-BSA as described (Horiuchi et al, 1991). 6D12 recognizes $C M L$ and its isotype is IgG1 (Ikeda et al, 1996). KNH-30, a monoclonal antibody specific for CEL, was generated by immunizing $\mathrm{BALB} / \mathrm{c}$ mice with CEL-human serum albumin; its isotype is IgG1. 1F6 was obtained from BALB/c mice immunized with fluorolink conjugated with BSA; its isotype is $\operatorname{lgM}$. The chemical structure of fluorolink, initially called $X 1$, was determined to be 1,7disubstituted 5-(1, 2, 3, 4-tetrahydroxybutyl)-1,4dihydro-4-oxo-1,7-naphthyridinium cation, two lysine molecules cross-linked via a pyridinium fluorophore composed of two glucose molecules (Horiuchi et al, 1996). To produce $2 A 2$, we immunized BALB/c mice with AGE-RNase and screened clones positive for AGE-BSA but negative for both CML-BSA and RNase. One of two clones obtained was called $2 \mathrm{~A} 2$ and its isotype is IgG1. The epitope of 2A2 is unknown, but our recent immunochemical study has indicated that $2 \mathrm{~A} 2$ recognizes a late non-CML structure that is oxidation-dependent (lkeda et al, 1998).

For the immunoabsorption test, the anti-AGE monoclonal antibodies were preincubated with an excess of AGE-BSA at $37^{\circ} \mathrm{C}$ for 1 hour, after which their immunoreactivities were completely abolished. Nonimmune mouse lgG1 and IgM (purchased from Dako, Glostrup, Denmark) were used as negative controls, and the staining results showed no immunoreaction. In addition, a polyclonal anti-insulin antibody (Dako) was used in this study.

\section{Immunohistochemistry}

For each adult rat or fetus tissue, several to 10 frozen cryostat sections were cut and put onto one slide and stained by the indirect immunoperoxidase method using the monoclonal antibodies. Briefly, after inhibi-

\begin{tabular}{|c|c|c|c|c|}
\hline Characteristic & 6D12 & KNH-30 & $1 \mathrm{~F} 6$ & $2 \mathrm{~A} 2$ \\
\hline Subclass & IgG1 & IgG1 & IgM & IgG1 \\
\hline Epitope & $\mathrm{CML}^{*}$ & CEL** & Fluorolink & Unknown \\
\hline Structure & $\begin{array}{l}\text { Lys } \\
1 \\
\mathrm{NH} \\
1 \\
\mathrm{CH}_{2} \\
1 \\
\mathrm{C}=\mathrm{O} \\
1 \\
\mathrm{OH}\end{array}$ & $\begin{array}{c}\text { Lys } \\
\mathrm{NH} \\
\mathrm{I} \\
-\mathrm{C}-\mathrm{CH}_{3} \\
\mathrm{C}=\mathrm{O} \\
\mathrm{I}=\mathrm{O} \\
\mathrm{OH}\end{array}$ & $\stackrel{\mathrm{OH}}{\mathrm{l}}$ & \\
\hline
\end{tabular}

Figure 7.

Subclasses, epitopes, and structures of anti-AGE monoclonal antibodies. ${ }^{*}, C M L, N^{*}$-(carboxymethyl)lysine; ${ }^{* *}, C E L, N^{\epsilon}$-(carboxyethyl)lysine. 
tion of endogenous peroxidase activity (Isobe et al, 1977), the sections were incubated with the monoclonal antibodies (diluted 1:500 for 6D12, 1:20 for KNH30, 1:10 for 2A2, and 1:100 for 1F6), washed, and reacted with peroxidase-labeled antimouse $\mathrm{F}\left(\mathrm{ab} \mathrm{b}^{\prime}\right)_{2}$ (Amersham, Poole, United Kingdom) diluted 1:100 as the second antibody. After treatment with 3-amino-9ethylcarbazole (Aldrich Chemical, Milwaukee, Wisconsin) (Graham et al, 1965), the sections were counterstained with hematoxylin and mounted with aqueous mounting medium (Merck, Darmstadt, Germany). For negative controls, the same procedures were performed, but the first antibodies were omitted. Although unfixed tissue samples were not well preserved, the immunostaining results for all four antiAGE monoclonal antibodies were similar to those for the $2 \%$ periodate-lysine-paraformaldehyde-fixed samples (not shown).

For the figures, after light-microscopic examination of the slides, a representative section was selected from each tissue and photographed, excluding sections showing the most intense or weakest immunostaining with each monoclonal antibody for AGEspecific molecules.

\section{RP-HPLC}

The 6-aminoquinolyl- $N$-hydroxysuccinimidyl carbamatelabeled samples were analyzed with an RP-HPLC. The RP-HPLC system was equipped with a C-18 column (150 $\times 3 \mathrm{~mm}$, Mightysile RP-18; Kanto Chemical, Tokyo, Japan) connected to a high-pressure gradient system consisting of two pumps (L7000; Hitachi, Tokyo, Japan), a degassing unit (DG660; GL Sciences, Tokyo, Japan), a column oven (L7300; Hitachi), a fluorescence spectrophotometer (F6000; Hitachi) with excitation at $250 \mathrm{~nm}$ and emission at $395 \mathrm{~nm}$, and a chromato-intregrator (D2500; Hitachi). The buffer $\mathrm{A}$ gradient was $100 \%$ to $71 \%$ from 0 to 52 minutes at $37^{\circ} \mathrm{C}$ at a flow rate of $0.5 \mathrm{ml} /$ minute (buffer $\mathrm{A}=140 \mathrm{~mm}$ of sodium acetate with $17 \mathrm{~mm}$ of triethylamine titrated to $\mathrm{pH}$ 5.05; buffer $B=60 \%$ acetonitrile/40\% deionized water). Because CML is known to be a dominant AGE antigen in tissue proteins (lkeda et al, 1996; Reddy et al, 1995), we used CML as a parameter of AGE in our HPLC assay. The peak of $C M L$ in the sample was identified via elution time and confirmed by coelution with a CML standard. The CML levels were expressed relative to the lysine content of the samples. CML content was quantitated with the CML standard curve, which was established with known amounts of CML (2-100 pmol) and lysine (50-5000 pmol) standards. CML was also detected by amino acid analysis, using an ion exchange HPLC column (\#2622 SC, $4.6 \times 60$ $\mathrm{mm}$; Hitachi) and the ninhydrin post-column detecting system, as described previously (lkeda et al, 1996).

\section{Statistical Analysis}

Data are expressed as means \pm SD. The significance of the differences between two groups was analyzed by unpaired Student's $t$ test. $p<0.05$ was considered significant.

\section{References}

Ahmed MU, Brinkmann Frye E, Degenhardt TP, Thorpe SR, and Baynes JW (1997). $N^{\epsilon}$-(Carboxyethyl)lysine, a product of the chemical modification of proteins by methylglyoxal, increases with age in human lens proteins. Biochem $\mathrm{J} 324$ : 565-570.

Ahmed MU, Thorpe SR, and Baynes JW (1986). Identification of $N^{\epsilon}$-(carboxymethyl)lysine as a degradation product of fructoselysine in glycated protein. J Biol Chem 261:48894894.

Anderson MM, Requena JR, Crowley JR, Thorpe SR, and Heinecke JW (1999). The myeloperoxidase system of human phagocytes generates $N^{\epsilon}$-(carboxymethyl)lysine on protein: A mechanism for producing advanced glycation end products at sites of inflammation. J Clin Invest 104:103-113.

Araki N, Ueno N, Chakrabarti B, Morino Y, and Horiuchi S (1992). Immunochemical evidence for the presence of advanced glycation end products in human lens proteins and its positive correlation with aging. J Biol Chem 267:1021110214.

Avogaro A, Calo L, Piarulli F, Miola M, deKreutzenberg S, Maran A, Burlina A, Mingardi R, Tiengo A, and Del Prato S (1999). Effect of acute ketosis on the endothelial function of type 1 diabetic patients: The role of nitric oxide. Diabetes 48:391-397.

Berg TJ, Dahl-Jorgensen K, Torjesen PA, and Hanssen KF (1997). Increased serum levels of advanced glycation end products (AGEs) in children and adolescents with IDDM. Diabetes Care 20:1006-1008.

Brownlee M, Cerami A, and Vlassara H (1988). Advanced glycosylation end products in tissue and the biochemical basis of diabetic complications. N Engl J Med 318:13151321.

Bucala R, Makita Z, Koschinsky T, Cerami A, and Vlassara H (1993). Lipid advanced glycosylation: Pathway for lipid oxidation in vivo. Proc Natl Acad Sci USA 90:6434-6438.

Bucala R, Model P, and Cerami A (1984). Modification of DNA by reducing sugars: A possible mechanism for nucleic acid aging and age-related dysfunction in gene expression. Proc Natl Acad Sci USA 81:105-109.

Castellani R, Smith MA, Richey PL, and Perry G (1996). Glycoxidation and oxidative stress in Parkinson disease and diffuse Lewy body disease. Brain Res 737:195-200

Cohen SA and Michaud DP (1993). Synthesis of a fluorescent derivatizing reagent, 6 -aminoquinolyl- $N$-hydroxysuccinimidyl carbamate, and its application for the analysis of hydrolysate amino acids via high-performance liquid chromatography. Anal Biochem 211:279-287.

Daugherty A, Dunn JL, Rateri DL, and Heinecke JW (1994). Myeloperoxidase, a catalyst for lipoprotein oxidation, is expressed in human atherosclerotic lesions. J Clin Invest 94: 437-444.

Degenhardt TP, Thorpe SR, and Baynes JW (1998). Chemical modification of proteins by methylglyoxal. Cell Mol Biol (Noisy-le-Grand) 44:1139-1145.

Dolhofer-Bliesener R, Lechner B, Deppisch R, Ritz E, and Gerbitz KD (1995). Immunological determination of advanced glycosylation end-products in human blood and urine. Nephrol Dial Transplant 10:657-664. 
Fehrenbach H, Kasper M, Tschernig T, Shearman MS, Schuh D, and Muller M (1998). Receptor for advanced glycation endproducts (RAGE) exhibits highly differential cellular and subcellular localisation in rat and human lung. Cell Mol Biol (Noisy-le-Grand) 44:1147-1157.

Fu S, Fu MX, Baynes JW, Thorpe SR, and Dean RT (1998). Presence of dopa and amino acid hydroperoxides in proteins modified with advanced glycation end products (AGEs): Amino acid oxidation products as a possible source of oxidative stress induced by AGE proteins. Biochem $\mathrm{J} 330$ : 233-239.

Glomb MA and Monnier VM (1995). Mechanism of protein modification by glyoxal and glycolaldehyde, reactive intermediates of the Maillard reaction. J Biol Chem 270:1001710026.

Graham R-C, Lundholm U, and Karnovsky MJ (1965). Cytochemical demonstration of peroxidase activity with 3-amino9-ethylcarbazole. J Histochem Cytochem 13:150-152.

Hamada Y, Araki N, Koh N, Nakamura J, Horiuchi S, and Hotta N (1996). Rapid formation of advanced glycation end products by intermediate metabolites of glycolytic pathway and polyol pathway. Biochem Biophys Res Commun 228: 539-543.

Hashimoto H (1998). The role of glycation in cataract lens in diabetic patients. Nippon Ganka Gakkai Zasshi 102:34-41.

Hayase F, Nagaraj RH, Miyata S, Njoroge FG, and Monnier VM (1989). Aging of proteins: Immunological detection of a glucose-derived pyrrole formed during Maillard reaction in vivo. J Biol Chem 264:3758-3764.

Horiuchi S, Araki N, and Morino Y (1991). Immunochemical approach to characterize advanced glycation end products of the Maillard reaction: Evidence for the presence of a common structure. J Biol Chem 266:7329-7332.

Horiuchi S, Araki N, Nakamura K, Ikeda K, Fukunaga Y, and lenaga K (1996). A new fluorescent crosslinker (AGE- $\times 1$ ) isolated from AGE-lysine derivatives. Diabetes 45(Suppl 2): 186A.

Hoshii Y, Kawano H, Gondo T, Takahashi M, Ishihara T, Higuchi K, and Horiuchi S (1996). Immunohistochemical study with anti-advanced glycation end-products antibody in murine amyloidosis. Pathol Int 46:738-742.

Ikeda K, Higashi T, Sano H, Jinnouchi Y, Yoshida M, Araki T, Ueda S, and Horiuchi S (1996). $N^{\epsilon}$-(Carboxymethyl)lysine protein adduct is a major immunological epitope in proteins modified with advanced glycation end products of the Maillard reaction. Biochemistry 35:8075-8083.

Ikeda K, Nagai R, Sakamoto T, Sano H, Araki T, Sakata N, Nakayama H, Yoshida M, Ueda S, and Horiuchi S (1998). Immunochemical approaches to AGE-structures: Characterization of anti-AGE antibodies. J Immunol Methods 215:95104.

Isobe Y, Chen ST, Nakane PK, and Brown WR (1977). Studies on translocation of immunoglobulins across interstitial epithelium. I. Improvements in the peroxidase-labeled antibody method for application to study of human interstitial mucosa. Acta Histochem Cytochem 10:161-171.

Jain SK, Kannan K, and Lim G (1998). Ketosis (acetoacetate) can generate oxygen radicals and cause increased lipid peroxidation and growth inhibition in human endothelial cells. Free Radic Biol Med 25:1083-1088.
Jain SK and McVie R. (1999). Hyperketonemia can increase lipid peroxidation and lower glutathione levels in human erythrocytes in vitro and in type 1 diabetic patients. Diabetes 48:1850-1855.

Jobst K and Lakatos $\AA$ (1996). The liver cell histones of diabetic patients contain glycation endproducts (AGEs) which may be lipofuscin components. Clin Chim Acta 256:203-204.

Karasik A and Hattori M (1994). Use of animal models in the study of diabetes. In: Kahn CR and Weir GC, editors. Joslin's diabetes mellitus. Philadelphia: Lea \& Febiger, 317-350.

Katsuoka F, Kawakami Y, Arai T, Imuta H, Fujiwara M, Kanma $\mathrm{H}$, and Yamashita K (1997). Type II alveolar epithelial cells in lung express receptor for advanced glycation end products (RAGE) gene. Biochem Biophys Res Commun 238:512-516.

Koschinsky T, He CJ, Mitsuhashi T, Bucala R, Liu C, Buenting C, Heitmann K, and Vlassara H (1997). Orally absorbed reactive glycation products (glycotoxins): An environmental risk factor in diabetic nephropathy. Proc Natl Acad Sci USA 94:6474-6479.

Kume S, Takeya M, Mori T, Araki N, Suzuki H, Horiuchi S, Kodama T, Miyauchi Y, and Takahashi K (1995). Immunohistochemical and ultrastructural detection of advanced glycation end products in atherosclerotic lesions of human aorta with a novel specific monoclonal antibody. Am J Pathol 147:654-667.

Layton GJ and Jerums G (1988). Effect of glycation of albumin on its renal clearance in normal and diabetic rats. Kidney Int 33:673-676.

Like AA and Rossini AA (1976). Streptozotocin-induced pancreatic insulitis: New model of diabetes mellitus. Science 193:415-417.

Ling X, Sakashita N, Takeya M, Nagai R, Horiuchi S, and Takahashi K (1998). Immunohistochemical distribution and subcellular localization of three distinct specific molecular structures of advanced glycation end products in human tissues. Lab Invest 78:1591-1606.

Maillard LC (1912). Action des acides amines sur les sucres: Formation des mélanoidines par voie méthodique. C R Acad Sci (Paris) 154:66-68.

Matsuse T, Ohga E, Teramoto S, Fukayama M, Nagai R, Horiuchi S, and Ouchi Y (1998). Immunohistochemical localisation of advanced glycation end products in pulmonary fibrosis. J Clin Pathol 51:515-519.

Mclellan AC, Thornalley PJ, Benn J, and Sonksen PH (1994). Glyoxalase system in clinical diabetes mellitus and correlation with diabetic complications. Clin Sci 87:21-29.

Mitsuhashi T, Nakayama H, Itoh T, Kuwajima S, Aoki S, Atsumi T, and Koike T (1993). Immunochemical detection of advanced glycation end products in renal cortex from STZinduced diabetic rat. Diabetes 42:826-832.

Mitsuhashi T, Vlassara H, Founds HW, and Li YM (1997). Standardizing the immunological measurement of advanced glycation endproducts using normal human serum. J Immunol Methods 207:79-88.

Miyata $\mathrm{T}$, Ishiguro $\mathrm{N}$, Yasuda $\mathrm{Y}$, Ito $\mathrm{T}$, Nangaku M, Iwata $\mathrm{H}$, and Kurokawa K (1998). Increased pentosidine, an advanced glycation end product, in plasma and synovial fluid from patients with rheumatoid arthritis and its relation with inflammatory markers. Biochem Biophys Res Commun 244:45-49. 
Mizutari K, Ono T, Ikeda K, Kayashima K, and Horiuchi S (1997). Photo-enhanced modification of human skin elastin in actinic elastosis by $N^{\epsilon}$-(carboxymethyl)lysine, one of the glycoxidation products of the Maillard reaction. J Invest Dermatol 108:797-802.

Mori T, Takahashi K, Higashi T, Takeya M, Kume S, Kawabe Y, Kodama T, and Horiuchi S (1995). Localization of advanced glycation end products of Maillard reaction in bovine tissues and their endocytosis by macrophage scavenger receptors. Exp Mol Pathol 63:135-152.

Munch G, Keis R, Wessels A, Riederer P, Bahner U, Heidland A, Niwa T, Lemke HD, and Schinzel R (1997). Determination of advanced glycation end products in serum by fluorescence spectroscopy and competitive ELISA. Eur J Clin Chem Clin Biochem 35:669-677.

Nagai R, Ikeda K, Higashi T, Sano H, Jinnouchi Y, Araki T, and Horiuchi $S$ (1997). Hydroxyl radical mediates $N^{\epsilon}$ (carboxymethyl)lysine formation from Amadori product. Biochem Biophys Res Commun 234:167-172.

Nagai R, Matsumoto K, Ling X, Suzuki H, Araki T, and Horiuchi S (2000). Glycolaldehyde, a reactive intermediate for advanced glycation endproducts, plays an important role in the generation of an active ligand for the macrophage scavenger receptor. Diabetes 49:1714-1723.

Nagaraj RH, Shipanova IN, and Faust FM (1996). Protein cross-linking by the Maillard reaction. J Biol Chem 271: 19338-19345.

Nakamura K, Hasegawa T, Fukunaga Y, and lenaga K (1992). Cross-lines $A$ and $B$ as candidates for the fluorophores in age- and diabetes-related cross-linked proteins, and their diacetates predicted by Maillard reaction of $\alpha-N$-acetyl-Llysine with D-glucose. J Chem Soc Chem Commun 14:992994.

Nakamura K, Nakazawa Y, and lenaga K (1997). Acid-stable fluorescent advanced glycation end products: Vesperlysines $\mathrm{A}, \mathrm{B}$, and $\mathrm{C}$ are formed as crosslinked products in the Maillard reaction between lysine or proteins with glucose. Biochem Biophys Res Commun 232:227-230.

Nakayama H, Mitsuhashi T, Kuwajima S, Aoki S, Kuroda Y, Itoh T, and Nakagawa S (1993). Immunochemical detection of advanced glycation end products in lens crystallins from streptozocin-induced diabetic rat. Diabetes 42:345-350.

Nauseef WM (1988). Myeloperoxidase deficiency. Hematol Oncol Clin North Am 2:135-158.

Niwa $T$, Katsuzaki $T$, Ishizaki $Y$, Hayase $F$, Miyazaki $T$, Uematsu T, Tatemichi N, and Takei Y (1997). Imidazolone, a novel advanced glycation end product, is present at high levels in kidneys of rats with streptozotocin-induced diabetes. FEBS Lett 407:297-302.

Obayashi H, Nakano K, Shigeta H, Yamaguchi M, Yoshimori K, Fukui M, Fujii M, Kitagawa Y, Nakamura N, Nakamura K, Nakazawa $Y$, lenaga K, Ohta M, Nishimura M, Fukui I, and Kondo M (1996). Formation of crossline as a fluorescent advanced glycation end product in vitro and in vivo. Biochem Biophys Res Commun 226:37-41.

Odani H, Shinzato T, Usami J, Matsumoto Y, Frye EB, Baynes JW, and Maeda K (1998). Imidazolium crosslinks derived from reaction of lysine with glyoxal and methylglyoxal are increased in serum proteins of uremic patients: Evidence for increased oxidative stress in uremia. FEBS Lett 427:381385.
Orth JM, Murray FT, and Bardin CW (1979). Ultrastructural changes in Leydig cells of streptozotocin-induced diabetic rats. Anat Rec 195:415-430.

Paz G and Homonnai ZT (1979). Leydig cell function in streptozotocin-induced diabetic rats. Experientia 35:14121413.

Reddy S, Bichler J, Wells-Knecht KJ, Thorpe SR, and Baynes JW (1995). $N^{\epsilon}$-(Carboxymethyl)lysine is a dominant advanced glycation end product (AGE) antigen in tissue proteins. Biochemistry 34:10872-10878.

Reichard GA Jr, Skutches CL, Hoeldtke RD, and Owen OE (1986). Acetone metabolism in humans during diabetic ketoacidosis. Diabetes 35:668-674.

Richard JP (1991). Kinetic parameters for the elimination reaction catalyzed by triosephosphate isomerase and an estimation of the reaction's physiological significance. Biochemistry 30:4581-4585.

Robert LG and Jonathan SM (1983). The principal site of nonenzymatic glycosylation of human serum albumin in vivo. J Biol Chem 258:6142-6146.

Sakai H, Jinde K, Suzuki D, Yagame M, and Nomoto $Y$ (1996). Localization of glycated proteins in the glomeruli of patients with diabetic nephropathy. Nephrol Dial Transplant 11(Suppl 5):66-71.

Sasaki N, Fukatsu R, Tsuzuki K, Hayashi Y, Yoshida T, Fujii N, Koike T, Wakayama I, Yanagihara R, Garruto R, Amano N, and Makita $Z$ (1998). Advanced glycation end products in Alzheimer's disease and other neurodegenerative diseases. Am J Pathol 153:1149-1155.

Schmidt AM, Weidman E, Lalla E, Yan SD, Hori O, Cao R, Brett JG, and Lamster IB (1996). Advanced glycation endproducts (AGEs) induce oxidant stress in the gingiva: $A$ potential mechanism underlying accelerated periodontal disease associated with diabetes. J Periodontal Res 31:508515.

Schnider SL and Kohn RR (1981). Effects of age and diabetes mellitus on the solubility and nonenzymatic glycosylation of human skin collagen. J Clin Invest 67:1630-1635.

Seftel AD, Vaziri ND, Ni Z, Razmjouei K, Fogarty J, Hampel N, Polak J, Wang RZ, Ferguson K, Block C, and Haas C (1997). Advanced glycation end products in human penis: Elevation in diabetic tissue, site of deposition, and possible effect through iNOS or eNOS. Urology 50:1016-1026.

Sell DR and Monnier VM (1989). Structure elucidation of a senescence cross-link from human extracellular matrix: Implication of pentoses in the aging process. J Biol Chem 264:21597-21602.

Smedsrød B, Melkko J, Araki N, Sano H, and Horiuchi S (1997). Advanced glycation end products are eliminated by scavenger-receptor mediated endocytosis in hepatic sinusoidal Kupffer and endothelial cells. Biochem J 322:567-573.

Smith PK, Krohn RI, Hermanson GT, Mallia AK, Gartner FH, Provenzano MD, Fujimoto EK, Goeke NM, Olson BJ, and Klenk DC (1985). Measurement of protein using bicinchoninic acid. Anal Biochem 150:76-85.

Stitt AW, Moore JE, Sharkey JA, Murphy G, Simpson DA, Bucala R, Vlassara H, and Archer DB (1998). Advanced glycation end products in vitreous: Structural and functional implications for diabetic vitreopathy. Invest Ophthalmol Vis Sci 39:2517-2523. 
Suzuki H, Kurihara Y, Takeya M, Kamada N, Kataoka M, Jishage $K$, Ueda $O$, Sakaguchi $H$, Higashi $T$, Suzuki $T$, Takashima Y, Kawabe Y, Cynshi O, Wada Y, Honda M, Kurihara $\mathrm{H}$, Aburatani $\mathrm{H}$, Doi $\mathrm{T}$, Matsumoto A, Azuma $\mathrm{S}$, Noda T, Toyoda Y, Itakura H, Yazaki Y, Horiuchi S, Takahashi K, Kruijt JK, van Berkel TJC, Steinbrecher UP, Ishibashi S, Maeda N, Gordon S, and Kodama T (1997). A role for macrophage scavenger receptors in atherosclerosis and susceptibility to infection. Nature 386:292-296

Thornalley PJ (1996). Pharmacology of methylglyoxal: Formation, modification of proteins and nucleic acids, and enzymatic detoxification: A role in pathogenesis and antiproliferative chemotherapy. Gen Pharmacol 27:565-573.

Thornalley PJ, Langborg A, and Minhas HS (1999). Formation of glyoxal, methylglyoxal and 3-deoxyglucosone in the glycation of proteins by glucose. Biochem J 344:109-116.

Tobler A and Koeffler HP (1991). Myeloperoxidase: Localization, structure and function. In: Harris JR, editor. Blood cell biochemistry 3: Lymphocytes and granulocytes. New York: Plenum Press, 255-288.

Uchida K, Khor OT, Oya T, Osawa T, Yasuda Y, and Miyata $T$ (1997). Protein modification by a Maillard reaction intermediate methylglyoxal: Immunochemical detection of fluorescent 5-methylimidazolone derivatives in vivo. FEBS Lett 410:313-318.

Vlassara H, Bucala R, and Striker L (1994). Pathogenic effects of advanced glycosylation: Biochemical, biologic, and clinical implications for diabetes and aging. Lab Invest 70 : 138-151.
Vlassara H, Li YM, Imani F, Wojciechowicz D, Yang Z, Liu FT, and Cerami A (1995). Identification of galectin-3 as a highaffinity binding protein for advanced glycation end products (AGE): A new member of the AGE-receptor complex. Mol Med 1:634-64

Wautier JL, Wautier MP, Schmidt AM, Anderson GM, Hori O, Zoukourian C, Capron L, Chappey O, Yan SD, Brett J, Guillausseau PJ, and Stern D (1994). Advanced glycation end products (AGEs) on the surface of diabetic erythrocytes bind to the vessel wall via a specific receptor inducing oxidant stress in the vasculature: A link between surface-associated AGEs and diabetic complications. Proc Natl Acad Sci USA 91:7742-7746.

Wells-Knecht KJ, Brinkmann E, Wells-Knecht MC, Litchfield JE, Ahmed MU, Reddy S, Zyzak DV, Thorpe SR, and Baynes JW (1996). New biomarkers of Maillard reaction damage to proteins. Nephrol Dial Transplant 11(Suppl 5):41-47.

Wells-Knecht MC, Thorpe SR, and Baynes JW (1995). Pathways of formation of glycoxidation products during glycation of collagen. Biochemistry 34:15134-15141.

Wiechelman KJ, Braun RD, and Fitzpatrick JD (1988). Investigation of the bicinchoninic acid protein assay: Identification of the groups responsible for color formation. Anal Biochem 175:231-237.

Youssef S, Soulis T, and Cooper ME (1998). Hepatic advanced glycation endproduct binding is increased in experimental diabetes. Cell Mol Biol (Noisy-le-Grand) 44:10951100. 